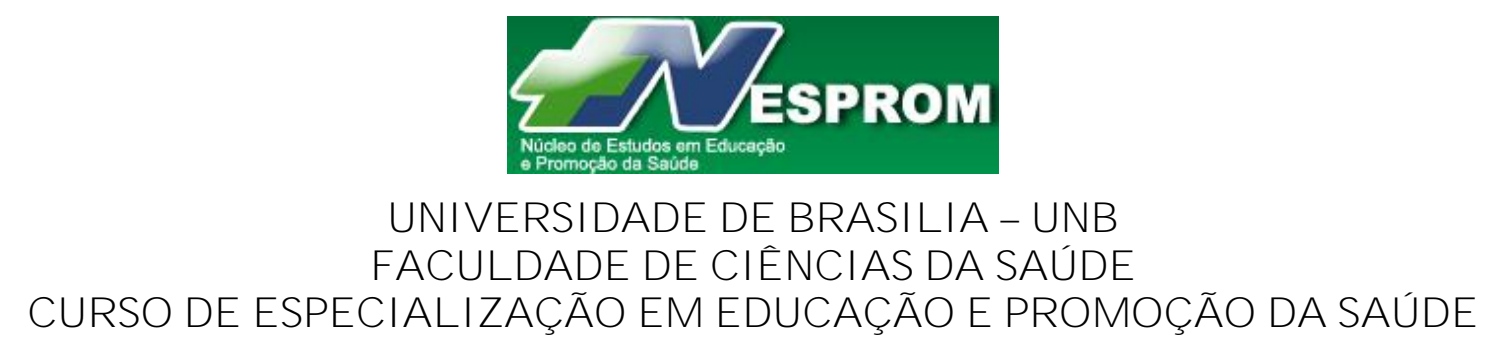

O IMPACTO DO USO NOCIVO DE ÁlCOOL NO TRABALHO

SANDRA MARIA GADELHA 
SANDRA MARIA GADELHA

\section{O IMPACTO DO USO NOCIVO DE ÁLCOOL NO TRABALHO}

Trabalho de Conclusão de Curso apresentado como requisito parcial da obtenção do grau de especialista em Educação e Promoção da Saúde do Curso de Educação e Promoção da Saúde da Universidade de Brasília - UnB.

Professora: Msc. Carolina C. Prado

Brasília-DF, 
Aos meus pais (in memorian), J osé Gadel ha e Maria Alves da Silva, por teremme preparado para a vida, muita saudade! Aos meus sobrinhos filhos, Tiago, Tassia, Tales eCaio, que representamo futuro e esperança de ummundo mel hor. 


\section{AGRADECIMENTOS}

Durante o percurso para a realização deste trabalho, é claro que encontrei dificuldades, mas necessárias e prazerosas, pelas novas descobertas, hoje tão preciosas.

Para tanto, agradeço, primeiramente e sempre, a Deus, por me mostrar que todos os dias de nossas vidas representam um milagre, e que ser como eu sou é um grande presente.

Meus sinceros agradecimentos àqueles que estiveram comigo "lado a lado" neste caminho, Rodolfo Prado, mesmo virtual (mas tão presente!), nas suas mensagens otimistas e sábios comentários.

Carolina Prado, minha querida mestra (orientadora) por sua presteza e dedicação, meus bons pensamentos, bons sentimentos e boas palavras para você.

Não poderia esquecer o carrísmo professor Élionai, seu saber, sua atenção, sua graça e, principalmente, sua militância pela cidadania. Muito grata, foi um presente ter te conhecido.

A minha família: meus irmãos Franciscos e suas esposas, Márcia e Gilvanete, por me darem a certeza de que nunca vou estar só na vida.

Sou grata ao meu companheiro Álvaro, por realmente ser "companheiro", suportando, às vezes, minhas angústias, mas também compartilhando minhas alegrias, nesta jornada e em tantas outras.

Ao meu amigo Leonardo Ramos, por sua paciência e carinho para comigo nesta jornada.

À Conceição Portilho estatística, pela amizade e colaboração.

Ao professor Newton Horta, matemático, por sua presteza em colaborar comigo neste trajeto.

Ao Doutor Daniel Peixoto, médico e consultor em promoção da saúde, por suas afetuosas exigências.

Ao Edvaldo Sá, mestre em economia da saúde por sua contribuição e incentivo.

E, finalmente, a todos que direta ou indiretamente contribuíram para a realização deste trabalho. 


\section{RESUM 0}

O presente trabalho visa avaliar os prejuízos causados pelo uso nocivo de álcool envolvendo os custos diretos, indiretos e intangíveis. Trata-se de um estudo de caso com pessoa do sexo masculino de 50 anos, trabalhador de uma empresa do ramo imobiliário do Distrito Federal. Utilizou-se os seguintes instrumentos: Alcohol Dependence Data Questionnaire (SADD), Fagerstrom Test for Nicotine Dependence (FTND), Short Form Health Survevy (SF 12), The Drinker Inventory of Consequences (DRINC), University of Rhode Island Change Assessmente Scale (URICA), para mensurar o impacto da doença no trabalho utilizou-se o YLD componente do indicador DALY, diante do qual os achados podem ser considerados bastantes significativos, onde o peso da incapacidade encontrado foi de 5,74, superior aos dados populacionais que correspondem a 2,5\%. Desta forma enfatiza-se a importância de trabalhos de promoção e prevenção de saúde voltados para temática de uso nocivo de álcool no ambiente de trabalho, seja empresas públicas ou privadas, acredita-se que com isto diminuiria o absenteísmo, o presenteísmo, favorecer-se-ia uma melhor qualidade de vida, que certamente converter-se-ia em melhor produtividade contribuindo para o fortalecimento da empresa, com ganhos na a saúde ocupacional.

Palavras-Chave: Álcool, Doença no Trabalho, Promoção e Prevenção da Saúde, Saúde Ocupacional. 


\section{SUMÁRIO}

1 INTRODUÇÃ O

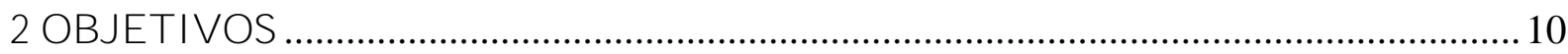

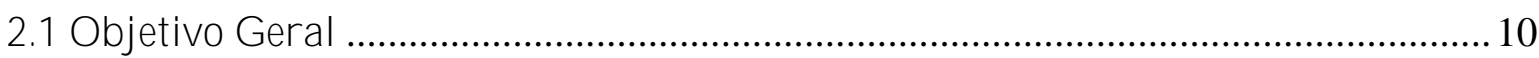

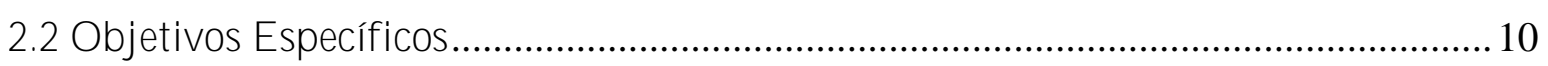

3 EFEITOS DO USO NOCIVO DE ÁLCOOL NO ORGANISMO HUMANO ….........11

3.1 Alcoolismo

3.2 A spectos Sócio-C ulturais do uso nocivo de Álcool ................................................ 15

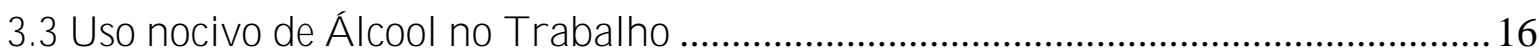

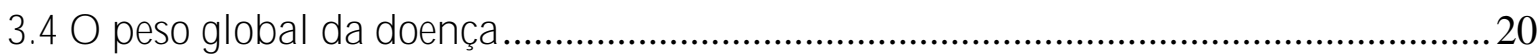

4 METODOLOGIA

5 ESTUDO DE CASO

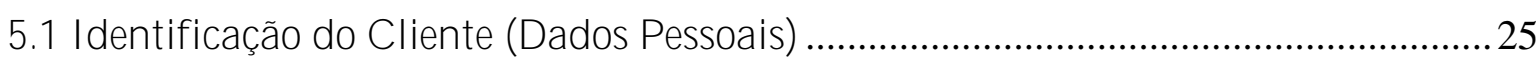

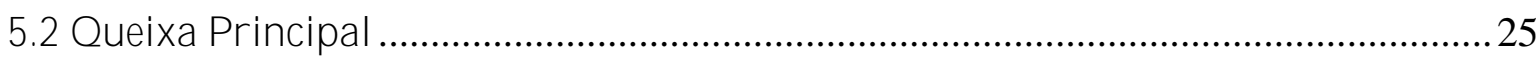

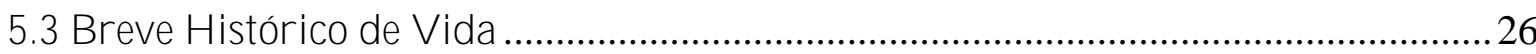

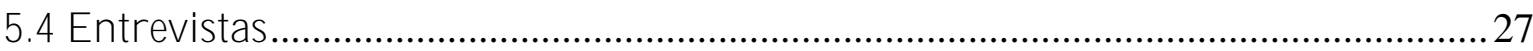

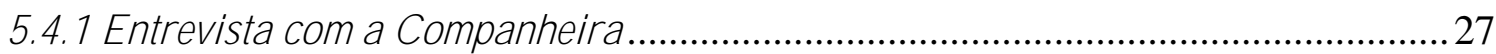

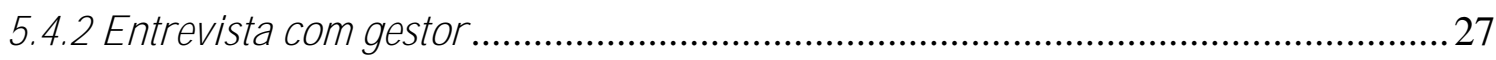

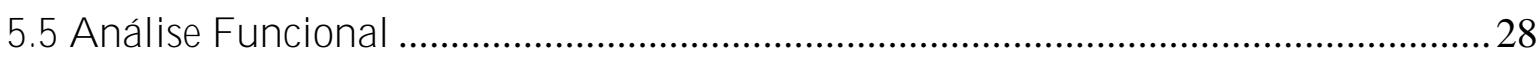

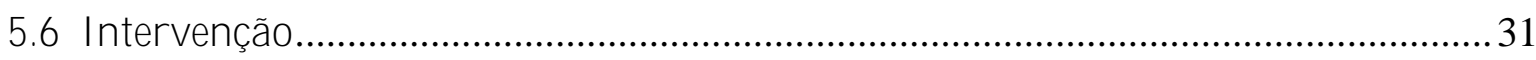

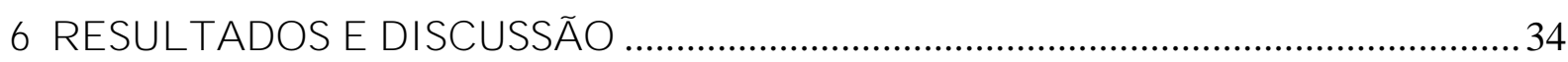

CONCLUSÃ O

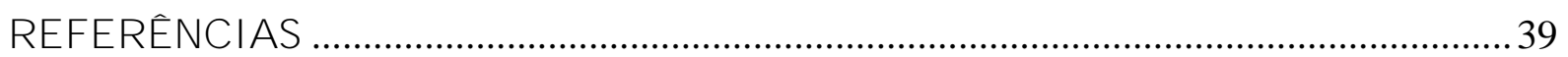




\section{INTRODUÇÃO}

O uso de álcool faz parte da história da humanidade há milênios, estando inserido na realidade social. Seu consumo está presente na maioria das culturas, variando, no entanto, seus padrões de uso, suas funções, seu alcance e sua frequência. Do uso social ao incontrolável, o álcool é a droga mais consumida no mundo.

Após a Revolução Industrial, o álcool passou a ser produzido em grandes quantidades, o que diminuiu seu custo e aumentou o seu consumo. Desde então, os médicos começaram a observar uma série de complicações físicas e mentais decorrentes de seu consumo excessivo.

O uso nocivo de álcool é um produto da sociedade contemporânea, a qual tem realizado diversas manobras a fim de construir comportamentos. A mídia, por exemplo, apresenta o álcool, em suas propagandas, sempre associado ao belo, ao saudável e ao sucesso. Nos últimos anos, vários estudos epidemiológicos sobre abuso e dependência de álcool têm sido conduzidos nos países desenvolvidos. O alcoolismo é considerado mundialmente um problema de saúde pública, tamanha a prevalência do consumo na população jovem e adulta.

Segundo a Organização Mundial de Saúde - OMS (2001, apud GALLASSI, 2008), a ingestão excessiva de álcool é a terceira causa de morte no mundo, depois do câncer e das cardiopatias. De acordo com o relatório divulgado sobre a saúde no mundo, das 20 doenças na faixa etária de 15 a 44 anos que acarretam anos vividos com alguma incapacidade, os transtornos relacionados ao abuso de álcool assumem o segundo lugar, com 55\%.

Carlini et al. (2005, apud GALLASSI, 2008), afirma que, no Brasil, aproximadamente $12,3 \%$ da população pode ser considerada dependente de álcool de acordo com os critérios da Codificação Internacional de Doenças CID-10 e do IV Manual de Diagnóstico e Estatística das Perturbações Mentais (DSM IV), sendo a prevalência de 17,1\% população masculina e 5,7\% na população feminina.

Para Scheinberg (1999 apud GALLASSI, 2008), dados especulativos estimam que o Brasil gaste, anualmente, 7,3\% do Produto Interno Bruto - PIB com conseqüências de problemas relacionados ao álcool, desde o tratamento das condições médicas até a perda da produtividade decorrente do seu uso. Considerando-se o PIB brasileiro do ano de 2004 em R\$ 
1,77 trilhões, estimava-se que o custo social referente a problemas devido ao abuso de álcool atingiria a cifra de $\mathrm{R} \$ 130$ bilhões por ano.

É importante chamar a atenção para os problemas sociais provocados pelo uso nocivo de álcool, dentre os quais é possível citar: vandalismo, violência doméstica, desordem pública, abuso de menores, problemas nas inter-relações familiares, habitação, dificuldades financeiras, criminalidade, problemas no trânsito e vitimização.

No que tange a Saúde Ocupacional, o uso nocivo de álcool apresenta índices consideráveis tanto para o absenteísmo, quanto para o presenteísmo, fatores estes que afetam diretamente a produtividade, com ênfase na baixa qualidade das tarefas desempenhadas. Tais aspectos permitem constatar um empobrecimento nas relações trabalhistas, bem como no processo de cidadania do individuo que produz o seu sustento e provê sua família. Entretanto, é importante frisar que muitos abusadores de álcool constroem sua doença no espaço trabalhista onde, erroneamente, se lança mão da bebida ao se desempenhar funções desagradáveis.

A qualidade de vida do usuário abusivo/dependente de álcool é afetada tanto nos aspectos do autocuidado, como também nas limitações dos papéis sociais, embora apresente um funcionamento empobrecido, o usuário sente-se satisfeito com sua qualidade de vida (LONGABAUGH et al.,1994).

Outro aspecto relevante que afeta severamente a qualidade vida do indivíduo dependente de álcool refere-se à saúde mental. O uso continum de álcool induz a complicações no Sistema Nervoso Central e Periférico, como convulsões, depressão, episódios de amnésia induzidos, entre outras, como também a doenças raras como, Síndrome de Wernicke-Korsaff, que provoca a desorientação no tempo e no espaço e a Doença de Marchiafava-Bignami, que, em sua forma aguda, gera desde agitação à incapacidade de caminhar (LARANJEIRA et al.,2004).

Considerando a definição de qualidade de vida apresentada pela OMS como sendo: “A percepção do individuo de sua posição na vida, no contexto de sua cultura e dos sistemas de valores em que vive e em relação a suas expectativas, a seus padrões e suas preocupações", pode-se compreender que os aspectos que permeiam a qualidade de vida constituem o biopsicossocial do indivíduo para a construção do seu papel no mundo, enquanto sujeito que atua. Sendo assim, entende-se que o uso nocivo/dependência de álcool provoca prejuízos 
irreparáveis. Apesar disto, observa-se que não há prioridade em tratar esta temática nos programas de saúde.

Entretanto, a cada dia emerge a necessidade de ações nesta área, desde a atenção primária à terciária. Apesar de a disponibilidade para atendimento na rede primária no Brasil ainda ser rara, deve-se promover ações que a contemple e valorize, pois o diagnóstico precoce aumenta a chance de sucesso da intervenção para tal população.

$\mathrm{Na}$ verdade, os problemas oriundos do uso nocivo de álcool são de grande prevalência e necessitam de políticas e ações que minimizem seus danos e previnam o surgimento de novos. Assim sendo, este estudo visa demonstrar os prejuízos causados pelo uso nocivo de álcool no trabalho. 


\section{OBJETIVOS}

\subsection{0 bjetivo G eral}

O objetivo geral deste estudo é demonstrar os prejuízos causados pelo uso nocivo de álcool em uma empresa de economia mista do ramo imobiliário do Distrito Federal, envolvendo os custos diretos, indiretos e intangíveis.

\subsection{Objetivos E specíficos}

Os objetivos específicos são:

B Identificar o custo total da doença, incluindo custos diretos, indiretos e intangíveis, provocados pelo uso nocivo de álcool no âmbito do trabalho de uma empresa de economia mista do ramo imobiliário do Distrito Federal;

B Avaliar os anos vividos com incapacidade (YLD) utilizando como referencial o indicador DALY;

ß Propiciar conteúdo para que empresas públicas e privadas priorizem em suas agendas políticas campanhas de promoção de saúde e programas de prevenção ao uso nocivo de álcool no âmbito empresarial. 


\section{EFEITOS DO USO NOCIVO DE ÁLCOOL NO ORGANISMO HUMANO}

O álcool (etanol) pode ser classificado como uma droga depressora do sistema nervoso central SNC, tomando como base sua ação bioquímica e o correspondente efeito clínico. Sua ingestão aguda provoca alterações em vários sistemas neuroquímicos cerebrais. $\mathrm{O}$ álcool estimula o sistema GABA, ácido gama-aminobutírico, que é o maior sistema inibitório cerebral e inibe o sistema glutamatérgico, que é o maior sistema estimulante do cérebro. Assim, o álcool incita o sistema à despolarização celular e inibe o sistema que estimula a despolarização. Esta ação corresponde aos diversos efeitos clínicos observados pelo uso agudo e crônico do álcool (BORDIN, FIGLIE, LARANJEIRA, 2004). Dentre os efeitos do uso nocivo de álcool, destacam-se a redução da ansiedade, os efeitos estimulantes e euforizantes e os efeitos anestésicos.

A ação ansiolítica acontece sobre o receptor GABA-a. O álcool intensifica a ação do ácido gama-aminobutírico GABA, o neurotransmissor mais importante do SNC, sobre o receptor GABA-a. Na prática, o indivíduo bebe para aliviar a ansiedade. Entretanto, após o efeito relaxante inicial, devido à sedação do sistema nervoso, ocorrerá uma espécie de excitação desconfortável do organismo e o usuário ficará mais ansioso, voltando, então, a beber a fim de conquistar um novo alívio. Este processo tem o potencial para desenvolver a dependência.

O suposto efeito estimulante do álcool pode ser explicado por sua ação no sistema mesolímbico do cérebro, que provoca liberação da dopamina, produzindo um reforço positivo associado ao sentimento de euforia ou recompensa, o que também pode explicar o desenvolvimento da dependência.

O álcool tem, ainda, uma ação anestésica que pode induzir a amnésia, efeitos provavelmente oriundos da ação inibitória do álcool sobre o receptor NMDA (N-metil-Daspartato). Os receptores NMDA são uma subclasse de receptores para o glutamato, o maior neurotransmissor excitatório do cérebro humano. Assim sendo, enquanto efeito anestésico, poderia ser recompensador numa depressão, já enquanto efeito amnésico, poderia ser recompensador em situações em que se queira amortecer memórias traumáticas. No entanto, o álcool potencializa os sentimentos preexistentes (BORDIN, FIGLIE, LARANJEIRA, 2004).

O uso nocivo de álcool provoca prejuízos irreparáveis à saúde, sendo um dos mais graves, o elevado número de mortes $(75 \%)$ por cirrose atribuídas ao alcoolismo (BORDIN, 
FIGLIE, LARANJEIRA, 2004). O uso continum também tem relação com o câncer em orofaringe, laringe, esôfago, fígado e mamas. O álcool por si só não é cancerígeno, mas pode potencializar a ação de agentes cancerígenos, diminuindo a proteção do organismo às células cancerosas.

Outro aspecto que merece atenção é a síndrome fetal alcoólica que ocorre em $30 \%$ a $50 \%$ de todos os bebês nascidos de mães alcoolistas. As crianças têm seu crescimento reduzido, anormalidades morfológicas no rosto e cabeça, deformidade nos membros e doenças cardíacas congênitas. Posteriormente, estas crianças apresentam deficiências cognitivas significativas (BORDIN, FIGLIE, LARANJEIRA, 2004).

O uso nocivo de álcool tanto pode causar como precipitar transtornos e doenças psiquiátricas, dentre as quais as mais comuns são:

ß Experiência alucinatória temporária: caracteriza-se por súbita e rapidamente, perturbação na percepção.

ß Delirium tremens e alucinose alcoólica: são complicações da abstinência. O Delirium caracteriza-se por obnubilação da consciência e confusão, alucinações vividas, afetando alguma modalidade sensorial e acentuado tremor. A Alucinose alcoólica caracteriza-se por alucinação auditiva.

ß Transtorno psicótico delirante induzido pelo álcool: é marcado tipicamente por delírios paranóides ou grandiosos, onde não há manifestação de confusão ou obnubilação da consciência.

ß Intoxicação patológica: caracteriza-se por um súbito comportamento agressivo e violento, não típico do individuo enquanto sóbrio. Ocorre logo após a ingestão de pequenas quantidades de álcool, as quais não produziriam intoxicação na maioria das pessoas.

ß Episódios de amnésia induzidos: os chamados blackouts alcoólicos referem-se à perda de memória transitória que pode ser induzida pela intoxicação.

ß Depressão: comum entre indivíduos com problemas com álcool e pode ser fator decisivo na busca do tratamento. Para que se defina se uma pessoa está infeliz ou com depressão é importante que se faça a avaliação de sua história. É mais 
sensato admitir que o diagnóstico não pode ser feito na presença do álcool e considerar a interrupção como pré-requisito para a resolução diagnóstica.

ß Suicídio: nos Estados Unidos, o risco é estimado em 3\% a 4\%. Em outros países ocidentais, este índice é de 60 a 120 vezes maior do que da população em geral. A comorbidade desempenha um papel importante, sendo a depressão o risco mais substancial. Perdas interpessoais e isolamento social também são fatores significativos.

B Ansiedade: estudos clínicos relatam uma associação entre alcoolismo e transtorno de ansiedade. Cerca de $30 \%$ dos alcoolistas podem ter uma experiência de ansiedade significativa.

ß Danos no tecido cerebral: as manifestações clínicas de comprometimento cerebral variam de déficits cognitivos leves, detectados somente por meio de testes psicométricos, até danos graves, que produzem incapacitação.

ß Transtornos de personalidade: existe uma estreita associação entre personalidade anti-social e consumo de álcool, sendo que o primeiro antecede o segundo, promovendo um consumo exagerado. Por outro lado, o consumo de álcool também pode levar a comportamentos menos anti-sociais.

ß Transtornos alimentares: os mais comuns são obesidade, que resulta da grande fonte calórica do álcool (sem valor nutricional) e a perda de peso, que está associada à má nutrição geral. Ambos são consequências da negligência dietética que normalmente acompanha o quadro.

B Esquizofrenia: é um problema que vem aumentando, provavelmente devido ao fato de que a maioria dos pacientes está vivendo em comunidades em que o acesso ao álcool é facilitado. Os esquizofrênicos podem se utilizar do álcool para lidar com o estresse associado à doença. $\mathrm{O}$ uso os torna mais propensos à violência e aumenta o risco de desenvolvimento de discinesia tardia (BORDIN, FIGLIE, LARANJEIRA, 2004). 


\subsection{Alcoolismo}

Um dos primeiros relatos sobre o uso excessivo de álcool ocorreu em 1790. Um médico americano descreveu que $30 \%$ dos pacientes internados em instituições psiquiátricas americanas da época faziam o uso excessivo do álcool. Outro pesquisador, também desenvolveu ideias avançadas sobre o hábito de beber para sua época, afirmando que "o hábito da embriaguês é uma doença da mente" (BORDIN, FIGLIE, LARANJEIRA, 2004, p. 31). Apesar de esses fatos terem ocorrido no século XIX, o debate sobre ser o beber excessivo uma doença ou não ainda é muito atual.

A partir da segunda metade do século XX, por volta de 1953, segundo Ramos e Bertolote (1997), parece ter sido Robert Straus e Selden Bacon os primeiros a publicar uma conceituação do alcoolismo como um fenômeno que se manifesta em várias dimensões, expressando-se ao longo de distintos eixos: físico, mas também psicológico e social.

Do ponto de vista epidemiológico, essa mudança é notável. O alcoolismo não deixou de ser considerado como uma doença, mas o fato de se constituir como tal é apenas um dos inúmeros problemas encontrados em associações com problemas relacionados ao consumo de álcool. Assim sendo, o conceito de alcoolismo acabou sendo ampliado e colocado dentro de uma perspectiva histórica e social.

Essa mudança se vinculava ao movimento mais generalizado de distanciamento da medicina de posições limitadamente organicistas e positivistas, observado a partir do final do século XIX. Essa nova posição ultrapassava a simples noção holística do biopsicossocial que, embora basicamente afirme que qualquer fenômeno mórbido deve ser entendido em toda a sua extensão relativa aos domínios físico, psicológico e social, limita-se, entretanto, ao conceito de doença. Em relação ao alcoolismo, a mais popular versão desse conceito foi publicada por Jellinek (apud RAMOS e BERTOLOTE, 1997), nos Estados Unidos, em 1960, amplamente disseminada pelo movimento dos Alcoólicos Anônimos.

Knupfer (apud RAMOS e BERTOLOTE, 1997), propõe um novo enfoque com a seguinte gama de problemas associados ao consumo de álcool: problemas familiares, problemas legais, problemas no trabalho, problemas de saúde (incluindo hospitalização) e problemas econômicos. 
Em 1976, Griffith e Milton, psiquiatra inglês e americano, respectivamente, apresentaram uma nova concepção para o conceito, propondo a compreensão do alcoolismo segundo um paradigma biaxial, psicopatologia do beber e problemas associados. Assim, surgiu o conceito de Síndrome de Dependência Alcoólica - SDA. Entende-se por síndrome um agrupamento de sinais e sintomas. Nem todos os elementos estão presentes em todos os casos, mas o quadro deve ser suficientemente regular e coerente para permitir seu reconhecimento clínico e a distinção entre síndrome e não síndrome. Este é o conceito usado até os dias atuais (BORDIN, FIGLIRE, LARANJEIRA, 2004).

\subsection{Aspectos Sócio-Culturais do uso nocivo de Álcool}

Cada sociedade tem colocado em relevo os padrões institucionalizados de uso das bebidas alcoólicas, a variedade de modos de produção, de motivos e de oportunidades construídas para o ato social de alcoolização. O catálogo dos motivos que referenciam as maneiras de beber não corresponde, necessariamente, ao resultado do comportamento, mas do aprendizado de atitudes culturalmente atribuídas aos diversos usos.

Em cada sociedade, o estabelecimento do contexto da ingestão de bebidas também se objetiva na construção de uma hierarquia entre as bebidas ou na construção de um significado especial para cada uma delas, o que é bem expresso no uso de bebidas variadas durante ou depois das refeições ou nas desqualificações atribuídas a aguardentes, em suas diversas possibilidades.

Nas sociedades ou nos contextos em que a alcoolização faz parte de um código de polidez, o abstinente é socialmente constrangido. Ela aparece de forma institucionalizada nas relações que se objetivam nos espaços de celebração do rito social de constituição do bom bebedor, como é o caso dos bares. A alcoolização se associa, para alguns, impositivamente, ao reconhecimento e internalização da identidade masculina. Nessas situações, a obrigação do uso do álcool como código de polidez tem a função de "lubrificante social" (NEVES, 2004).

Um dos argumentos que tem sido utilizado contra a determinação social do alcoolismo é o fato de ele alcançar todas as classes sociais, não discriminando pobres ou ricos. Deve-se ressaltar que a concepção social busca uma compreensão do alcoolismo em fatores sociais muito mais complexos de serem percebidos do que simplesmente o poder aquisitivo ou estrutura política. 
Existem muitas evidências de que normas culturais a respeito do consumo de álcool tem um papel importante no desenvolvimento do alcoolismo. Culturas que ensinam as crianças a beber responsavelmente, bem como as culturas que sugerem rituais estabelecidos de onde, quando e como beber tem menores taxas de uso nocivo de álcool quando comparadas às culturas que simplesmente proíbem as crianças de beber.

Talvez o exemplo mais claro da influência das normas culturais seja o que ocorre entre judeus, onde, apesar de o álcool ser habitualmente consumido, o número de abstêmios é baixo e tanto a embriaguês como o alcoolismo são pouco freqüentes (RAMOS, BERTOLOTE, 1997).

Varias hipóteses têm sido formuladas para explicar essa especificidade cultural em relação ao álcool. Já foi sugerido que, quando o ato de beber está intimamente relacionado às cerimônias e rituais religiosos, agiria no sentido de estabelecer uma atitude eminentemente ritualística frente ao beber nos indivíduos mais ortodoxos. Ou seja, esse ato seria essencialmente simbólico, afastando a possibilidade do beber com outras finalidades, como fuga de tensões ou de problemas, ao contrário do que é encorajado em outras culturas (RAMOS, BERTOLOTE, 1997).

Para Requelme (apud VAISSMAN, 2004), em outras culturas, como no Chile, por exemplo, o resultado é bem diferente. Em 1974, o Chile, que ainda hoje é grande produtor de vinho, possuía o triste recorde de ser o campeão mundial de taxas de mortalidade por cirrose hepática. Isso ocorria devido ao elevadíssimo consumo per capita de álcool, constituindo-se um dos maiores problemas de saúde institucional naquele país.

\subsection{Uso nocivo de Álcool no Trabalho}

A Associação dos Estudos do Álcool e outras Drogas - ABEAD estimou, em 1990, que a taxa de prevalência do alcoolismo variava entre $3 \%$ e $10 \%$ da população adulta e que o alcoolismo é o terceiro motivo para o absenteísmo no trabalho, sendo a causa mais freqüente de aposentadorias precoces e de auxilio-doença pela Previdência Social.

Para Kurtz et al. e Araújo et al. (apud VAISSMAN, 2004), o absenteísmo é representado pelas faltas não autorizadas, licenças por doenças, faltas de curta duração, com ou sem comprovação médica, faltas freqüentes nas segundas e sextas-feiras e nos dias que 
antecedem ou sucedem feriados, dias de trabalho extra para compensar faltas, faltas por doenças vagas como resfriado, gripes e enxaquecas.

Outro determinante que vem sendo estudado recentemente é o presenteísmo, o qual reflete a extensão mensurável em que os sintomas, condições e doenças afetam negativamente a produtividade no trabalho de pessoas que decidem permanecer no mesmo (LARRY CHAPMAN, 2009).

A queda na produtividade e qualidade do trabalho é representada pela diminuição regular da produtividade pela manhã ou faltas pela tarde, faltas a compromissos, necessidade de um tempo maior para realizar menos tarefas, desperdício de materiais, perda ou estrago de equipamentos, desculpas inconsistentes, alternância de períodos de alta e baixa produtividade, que se torna cada vez mais insatisfatória, dificuldades com instruções e procedimentos, dificuldades de reconhecer erros, dificuldades de entender novas instruções, dificuldades com tarefas complexas e hábitos de trabalho irregulares.

Menéndez (apud VAISSMAN, 2004) afirma que a sociedade capitalista, desde os primórdios dos processos de industrialização, precisou estabelecer controles ideológicospolíticos para o conjunto de extratos subalternos urbanos. Assim, o "perigo" do alcoolismo implica na apropriação médica de uma doença porque promove desordem e "loucura". Precisa ser controlado na medida em que afeta os objetivos centralizados no desenvolvimento empresarial, ou seja, a produtividade. A alcoolização não é apenas uma base de tumultos e de criminalidade, mas é a causa do absenteísmo no trabalho, de faltas e da manutenção de determinados ritmos produtivos.

Desde que se constatou que a performance do trabalhador e o ambiente de trabalho são altamente afetados pelas consequências do uso nocivo do álcool e de outras drogas, também se comprovou que o local de trabalho poderia ser o locus privilegiado de intervenções para a implantação e o desenvolvimento de programas assistenciais e de prevenção primária do alcoolismo e de outras drogas.

A prevenção do uso nocivo de álcool e drogas no trabalho tem sido preconizada por vários órgãos internacionais, como a OMS, por meio do Programa de Abuso de Substâncias PSA, a Internacional Labour Orgazation e a United Nations Internacional Drug Control Programme - UNDCP. Todos esses organismos privilegiam as ações de prevenção ao consumo de álcool e drogas no próprio local de trabalho, uma vez que se considera que $70 \%$ a 
$80 \%$ dos usuários de álcool e drogas estão empregados e a maior parte de seu tempo é despendido com e no trabalho. Além disso, o local de trabalho é considerado, depois da família, como o principal sistema social nas vidas de seus membros. Também se verificou que entre a idade de 20 a 35 anos, os malefícios do álcool estão muito mais relacionados com a intoxicação aguda resultante de acidentes, brigas e disputas e com a ausência ao trabalho, do que acontece na faixa etária entre 35 a 55 anos, em que os problemas relacionados ao álcool são resultantes de um consumo regular, incluindo os problemas físicos decorrentes, como dano hepático e as mudanças psiconeurológicas (VAISSMAN, 2004).

Ultimamente, os Estados Unidos vem utilizando os chamados Employment Assistence Programs - EAPs (Programa de Assistência aos Empregados), cujo objetivo e proposta básica de intervenção possuem um escopo bastante abrangente no que diz respeito à saúde mental e geral nos locais de trabalho, pois envolve programas direcionados para auxiliar os trabalhadores a lidar com um amplo espectro de problemas ligados às esferas do abuso de álcool e outras substâncias, problemas emocionais e psiquiátricos, familiares, conjugais, legais e financeiros. A finalidade dos EAPs é beneficiar tanto o empregador, que economiza recursos evitando demissões, rotatividade de mão-de-obra, recolocação e treinamento de novos empregados, como o trabalhador, que estaria arriscando o seu emprego e, então, se motivaria a buscar a ajuda do EAP (VAISSMAN, 2004).

Historicamente, estes programas foram desenvolvidos nos EUA e em alguns países como Canadá para lidar com os problemas do consumo excessivo de álcool pelos trabalhadores industriais norte-americanos, por meio de políticas de gerenciamento de recursos humanos, e tiveram como precursores os programas de alcoolismo ocupacionais, iniciados na década de 1940, com o Movimento de Alcoolismo Ocupacional (Formal Occupational Alcoholism Programs - OAPs), ainda atrelado ao movimento inicial dos Alcoólicos Anônimos, que se estruturava e se difundia nessa mesma época (MENDES e DIAS, 1991).

No Brasil, menos de 5\% das empresas tem algum tipo de programa de prevenção. Em países como Estados Unidos, Canadá, França e Inglaterra, esse índice chega a 90\%, mostrando o claro senso de responsabilidade social (SENAD, 2008).

Segundo Mendes e Dias (1991), o alcoolismo é a quinta patologia mais freqüentemente invocada para concessão de licenças de saúde e que causa maior incidência de 
ausências ao trabalho nas segundas-feiras e após o dia de pagamento, o que pode ser atribuído, segundo a prática dos gerentes de recursos humanos, ao uso nocivo de substâncias psicoativas nos dias antecedentes.

Empresas brasileiras, sobretudo as de grande porte, como Petrobras S/A e as de capital multinacional, passaram a desenvolver programas de prevenção e tratamento de álcool e drogas no local de trabalho, partindo da premissa que, para a relação custo/beneficio, é mais interessante implantar medidas preventivas do que meramente substituir o empregado da empresa, arcando-se com os custos de demissão, recrutamento, seleção e treinamento do novo empregado (VAISSMAN, 2004).

Após a implantação do Programa em Dependência Química da Refinaria Duque de Caxias, houve economia de 60 a $70 \%$ nas perdas ocasionadas no absenteísmo no trabalho, doença e número de acidentes, registrados pela saúde ocupacional (MELLO NETTO apud VAISSMAN 2004, p. 62).

Ângelo Campana (apud VAISSMAN, 2004) é o autor que melhor estudou a evolução histórica dos programas de álcool em empresas brasileiras. Didaticamente, afirma que os primeiros programas de alcoolismo no país surgiram nos anos 1980, inicialmente como cópia de projetos norte-americanos. Os programas brasileiros, contudo, seguiram uma trajetória diferente dessa matriz.

Distinguem-se, então, três momentos diferenciados: o primeiro segue o modelo conceitual de alcoolismo como doença, o mais comum ainda hoje, no país. São implantados nas empresas, por meio dos serviços médicos e/ou serviço social, o treinamento das chefias para identificação dos empregados com problemas, o confronto e o encaminhamento para tratamento em clínicas especializadas. Utilizam, para o acompanhamento na empresa, alcoólicos em recuperação, consultores alcoólicos, alcoólicos anônimos e internação em clínicas com modelo baseado na filosofia de grupos de auto-ajuda.

Num segundo momento, a partir de 1985, esses programas buscaram ampliar o seu espectro de ação, estendendo a sua abrangência para outras dependências químicas e outras prioridades de saúde do trabalhador, seguindo a recomendação da OMS de desenvolver programas de prevenção e tratamento da dependência química no ambiente de trabalho e na comunidade.

Um terceiro momento começa a engendrar nas empresas, quer sejam brasileiras ou estrangeiras: a verificação de que os programas em dependência química são muito dispendiosos e que a relação custo/beneficio não é favorável ao empregador. As empresas, 
hoje, vivem coincidentemente um período de reestruturação administrativa, com programas de qualidade de vida total e reengenharia, no qual se adéquam as metas, antes difíceis de alcançar, com programas de prevenção primária. Busca-se atingir tão somente o uso nocivo da substância, porém sem dependência grave, leve ou moderada.

Essas são as propostas que vêm sendo veiculadas atualmente nas empresas, pretendendo englobar as dependências químicas num campo mais abrangente, inclusive de promoção de saúde mental.

Para a Secretaria Nacional Antidrogas - SENAD (2008), o ambiente de trabalho é o espaço privilegiado para definir uma política de prevenção, uma vez que é um local onde o trabalhador passa grande parte de seu tempo e estabelece uma rede de relacionamento capaz de lhe conferir identidade social e profissional.

Embora a Consolidação das leis Trabalhistas - CLT, arcaicamente ainda legisle sobre a dispensa por justa causa para "embriaguez habitual ou em serviço", a demissão sumária do trabalhador com problemas de álcool e outras drogas vem perdendo a força. A substituição pura e simples não garante a solução, já que entre 10 e $12 \%$ da população economicamente produtiva, acima de 14 anos, têm problemas de abuso ou dependência de algum tipo de drogas (OIT, 1993).

\subsection{0 peso global da doença}

O extrato final de problemas relacionados ao consumo de álcool, no de 2000, foi apresentado por meio de um indicador de saúde designado DALYs (Disabillity Adjusted life Years - Anos de Vida Perdidos Ajustados por Incapacidade). Este indicador refere-se ao cálculo dos Anos de Vida Perdidos por Morte Prematura (YLL) mais os Anos de Vida Perdidos por Incapacidade (YLD). O DALY é atribuível à ingestão alcoólica. Naquele ano, foi encontrado um valor de $4 \%$ para todo o mundo.

Nos países em que a economia de mercado é pouco desenvolvida e em que as taxas de mortalidade geral são mais elevadas, como países da África, o álcool não chega a figurar entre as dez principais causas de adoecimento e morte. Embora seja também gravíssima a situação ligada ao seu consumo, problemas sanitários básicos ainda prevalecem. Nos blocos econômicos mais ricos, apesar da existência de programas de prevenção e controles eficazes, 
o consumo de álcool aparece como fator mais deletério à saúde, sendo o DALYs da América do Norte entre 4,0 e 7,9\%.

Para países com economia de mercado de pobreza intermediária, dentre os quais o Brasil, o álcool é o mais importante fator causal de doença e morte, podendo o impacto deletério total, dentro de uma escala percentual, ser considerado em patamares que variam de $8 \%$ até $14,9 \%$ do total de problemas de saúde dessas nações. Assim sendo, no Brasil, o consumo de álcool é o responsável por mais de 10\% dos problemas totais de saúde (MELONI, LARANJEIRA, 2004).

Murray e Lopez (BRASIL, 2008), em estudo realizado pela Universidade de Harvard sobre a carga global da doença, indicam que, das dez doenças mais incapacitantes em todo o mundo, cinco são de origem psiquiátrica: depressão, transtorno afetivo bipolar, alcoolismo, esquizofrenia e transtorno obsessivo compulsivo, sendo o álcool responsável por cerca de $1,5 \%$ de todas as mortes do mundo e de $2,5 \%$ do total de anos vividos ajustados para a incapacidade, incluindo transtornos físicos, como cirrose hepática e miocardiopatia, até lesões decorrentes de acidentes de automóvel e em indústrias.

Entre os problemas de ordem biopsicossocial decorrentes do abuso e/ou dependência alcoólica, que afetam tanto o próprio usuário quanto seus familiares, estão sofrimento e complicações físicas e mentais, desemprego, violência e criminalidade, mortalidade, morbidade. Todos estes problemas acarretam um elevado custo econômico para a sociedade. Entretanto, pouco tem sido feito para mensurar, quantitativamente, suas conseqüências no Brasil. Uma constatação da necessidade de ampliação desta discussão está no fato de que, atualmente, elementos fundamentais como os custos indiretos não estão sendo considerados nas estimativas de custos da dependência de álcool. Os custos indiretos atingem não só os abusadores/dependentes de álcool, mas também seus empregadores, que podem ter elevado gastos com perda da produtividade relacionada às licenças médicas e com o próprio consumo de álcool durante o trabalho (MORAES et. al., 2006).

Nesse sentido, os custos sócio-econômicos do uso nocivo de álcool podem ser classificados em: a) custos diretos, que estão diretamente relacionados à intervenção; b) custos indiretos, diretamente relacionados com a intervenção; e c) custos intangíveis, que são os mais difíceis de serem medidos ou valorados, pois se referem ao custo do sofrimento físico/psíquico. 


\section{METODOLOGIA}

Para que o objetivo proposto fosse atingido, foi realizado estudo de caso com um sujeito do sexo masculino, com 50 anos de idade, servidor público distrital, com 29 anos de serviço. A escolha deste deu-se durante uma triagem realizada com servidores, que atendendo ao convite da empresa em que trabalham em parceria com a operadora de saúde Unimed Centro Oeste e Tocantins, participaram desta iniciativa com o objetivo de implantar um serviço de assistência voltado para o trabalhador com problema de uso nocivo de álcool e outras drogas. Dentre os participantes o paciente em foco foi escolhido devido às reincindivas internações e longos períodos de afastamento do trabalho em virtude do uso de álcool. Para consecução dos objetivos de trabalho, adotou-se uma estratégia metodológica qualitativa.

Foram realizados os seguintes procedimentos: análise documental (prontuário médico); acompanhamento do paciente em sua atividade em campo, com o objetivo de observar seu desempenho em um dia de trabalho; entrevista com a companheira do paciente; entrevista com o gestor do trabalho; e três entrevistas com o paciente, sendo a primeira entrevista livre com o objetivo de estabelecer um rapport, a segunda entrevista estruturada, com duração média de uma hora, que continha a seguinte sequiência: Dados Demográficos idade, sexo, estado civil, escolaridade, ocupação e renda familiar e aplicação dos seguintes instrumentos:

B Alcohol Dependence Data Questionnaire (SADD), elaborado por Raistrick et al., (1983) da versão original (ADD) perfazendo 15 itens. Esta escala investiga o grau de severidade da dependência alcoólica em leve, moderada e grave, foi validada no Brasil por Jorge e Masur (1985), apresentando uma correlação do coeficiente de Spearman $r=.81$ e confiabilidade de teste - retest $r=.90$

B Fagerstrom Test for Nicotine Dependence (FTND), desenvolvido por Karl-Olov Fagerstrom (1978) e depois readaptado por Healtherton e colaboradores (1991), para ter consistência interna superior relacionada com índices bioquímicos do fumar. Consiste em seis questões referentes ao padrão típico de fumar, possibilitando a classificação da dependência de nicotina em leve, moderada e severa.

Já a terceira entrevista foi realizada em uma clínica de internação para onde o paciente foi encaminhado, a entrevista estruturou-se na seguinte seqüência: 
B Short Form Health Survevy (SF 12), que investiga o padrão de qualidade de vida por meio de uma avaliação genérica da saúde não especifica para uma determinada doença, idade ou grupo de tratamento. O Short From Health Survery (SF12) é derivado do SF36 composto de 36 itens é derivado de um questionário, com 149 itens, desenvolvido e testado em 22000 pacientes, como parte de um estudo de saúde. Em 1991, Ware e colaboradores, iniciaram um projeto de validação internacional deste questionário (Internacional Quality of Life Assessment Project) oficialmente em 14 países, além de 20 outros países. Este instrumento foi validado no Brasil por Cicconelli (1997) em pacientes portadores de artrite reumatóide, sendo encontrado reprodutibilidade, coeficiente de correlação de Pearson $=.44$ à .84 (intra-observador) e .55 à .81 (inter-observador). A escala conte com 36 que avaliam: Aspectos Físicos, Capacidade Funcional, Dor, Estado Geral de Saúde, Aspectos Sociais e Emocionais, Saúde Mental e Vitalidade. Estudo com alcoolistas revelou baixos escores em Capacidade Funcional e Saúde Mental, com efeitos variáveis conforme grau de dependência/abuso, quantidade e freqüência (VOLK et. al., 1997, apud FIGLIE 1999).

ß The Drinker Inventory of Consequences (DRINC), este instrumento composto de 50 itens avalia os problemas e consequiências decorrentes do hábito de beber como um constructo distinto do consumo e dependência nas esferas: física, interpessoal, intrapessoal, controle dos impulsos e responsabilidade social. Foi desenvolvido no Projeto MATCH para a descrição de clientes e avaliação do desfecho clínico, onde foi encontrada uma consistência interna $=91$ e confiabilidade teste-reteste $r$ = 94 (MILLER, et. al., 1995, apud FIGLIE, 1999).

ß University of Rhode Island Change Assessmente Scale (URICA), tem como objetivo estudar os estágios de mudança: Pré-contemplação, Contemplação, Ação e Manutenção, com consistência interna de 88 a 89 (MCCONNAUGH et al., 1983) referente a motivação do paciente que procura tratamento para modificação de qualquer tipo de problema (PROCHASKA e DI CLEMENTE, 1986). É composta por 32 itens que inicialmente foram testados em fumantes e posteriormente em alcoolistas, sendo que estudos têm demonstrado a utilidade na 
analise do perfil de alcoolistas, mas com presença de subtipos (DI CLEMENTE; HUGHES, 1990). Os instrumentos foram validados por Figlie (1999).

Para mesurar o impacto da doença do paciente e, assim, obter resultados relacionados ao peso da doença, buscou-se embasamento demonstrativo no indicador DALY. Porém, neste estudo, utilizou-se somente do componente YLD, devido ao foco estar voltado para os anos vida perdidos por incapacidade, em decorrência dos danos provocados pelo uso nocivo de álcool.

Figura 1 - Fórmula Y L D

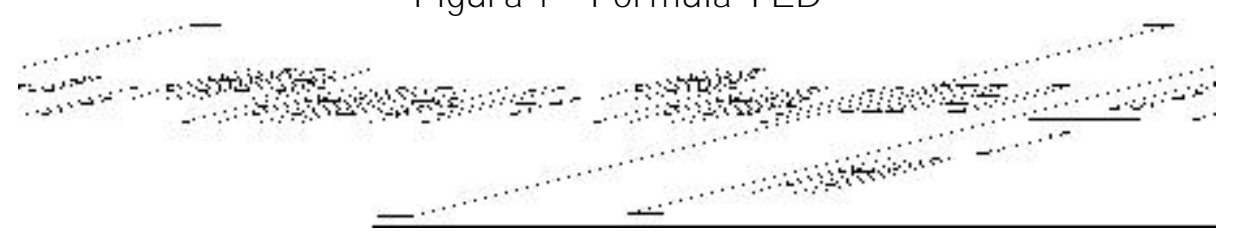

Sendo:

$\mathbf{r}$ - taxa de desconto;

â - parâmetro de função de ponderação da idade;

C - constante;

a - idade do surgimento da incapacidade;

L - duração da incapacidade;

D - peso da incapacidade;

E - constante de Euler. 


\section{ESTUDO DE CASO}

\subsection{I dentificação do Cliente (Dados Pessoais)}

Nome: C.A.M

Sexo: Masculino

Idade: 51 anos

\section{Estado Civil: Casado}

Nível Socioeconômico e cultural: salário acima da média para seu nível de escolaridade (segundo grau incompleto), porém ainda não tem casa própria, reside no entorno. As condições econômicas não permitem morar em outro local, pois sempre está com muitas dívidas.

\section{Religião: Católico}

Profissão: Servidor público (auxiliar de topografia)

Renda familiar: $\mathrm{R} \$ 5.632,00$ (cinco mil seiscentos e trinta e dois reais), bruto.

Observações relevantes: Além da bebida em excesso, outro aspecto importante é que o paciente é tabagista e joga "carteado".

\subsection{Queixa Principal}

O paciente procurou atendimento relatando que precisava de ajuda, pois não suportava mais continuar com o mesmo estilo de vida. Acordava às $04 \mathrm{~h} 00 \mathrm{~min}$ da manhã e começava a beber. Por volta das $14 \mathrm{~h} 00 \mathrm{~min}$, já havia consumido uma garrafa de conhaque presidente $(750 \mathrm{ml})$ e fumado um maço de cigarros. Estava com receio de voltar ao padrão atingido em 1999, em que chegou ao ponto de ingerir uma caixa de conhaque por semana (uma caixa contém 12 garrafas) e mais algumas doses de vodca. Ainda, queixa-se de uma forte depressão. 


\subsection{Breve H istórico de Vida}

Trata-se de indivíduo de 51 anos de idade, oriundo de uma prole de 17 filhos sendo que 12 morreram ainda criança, devido à desnutrição. Natural da Região Nordeste, migrou para Brasília com a família quando ainda era criança, seu pai fazia uso nocivo de bebida alcoólica e aos 8 anos de idade começou a beber e a fumar. Aos 10, sofreu uma agressão física do pai, um tapa na altura do ouvido direito que lhe deixou sequelas até os dias atuais. Aos 13 anos, a família voltou para o Nordeste, ocasião em que parou de estudar para trabalhar na feira e ajudar o pai a sustentar os irmãos. Após alguns anos, retornou à Brasília, onde trabalhou por algum tempo em uma empresa do ramo automobilístico, depois foi para o garimpo onde ficou por dois anos. Novamente em Brasília, casou-se e teve 03 filhos, sendo um do sexo feminino, hoje com 27 anos, e dois do sexo masculino, sendo um com 27 e outro com 26 anos. Sua esposa faleceu de aneurisma, por volta de 1981. Estabeleceu vida conjugal novamente e teve uma filha, hoje com 16 anos. Separou-se. Novamente estabeleceu vida conjugal com sua atual companheira, 27 anos mais nova, com quem tem um filho de 03 anos. Sua companheira já tinha 02 filhos, um menino de 09 anos e uma menina de 06 anos, a qual registrou como filha.

Em 1981, entrou para uma empresa pública do ramo imobiliário do Distrito Federal, onde trabalha atualmente, onde seu padrão do uso de bebida foi aumentando no decorrer dos anos.

Em 1972 pela primeira vez recorreu à internação, em virtude do uso nocivo de álcool, daí em diante foi uma sequiência de internações em clínicas e Comunidades Terapêuticas. Ficou sem beber do ano de 1997 a 1999 quando teve uma recaída, chegando ao seu ápice, período em que consumia uma caixa de conhaque por semana (12 garrafas de 790 ml). As maiores intercorrências são registradas de 2002 a 2006 com 1543 dias de licença para tratamento de saúde-LTS, seguida de 782 dias de 2007 a 2009. Em contagem geral, somam-se aproximadamente 08 anos de afastamento do trabalho em virtude do uso nocivo de álcool. 


\subsection{E ntrevistas}

\subsubsection{Entrevista coma Companheira}

E.A.C., 37 anos, vive maritalmente com C.A.M há 7 anos, tem 3 filhos sendo uma menina de 12 anos de idade, que o pai não reconheceu, sendo mais tarde reconhecida pelo seu atual companheiro. De outro relacionamento nasceu um menino, que hoje está com 9 anos de idade. Com o atual companheiro tem um filho de 3 anos de idade.

Relata que sua vida tem sido muito difícil, é natural da Bahia, foi criada pelos avós, sua mãe rejeitava os filhos logo que nasciam. Ainda era menor quando migrou para Brasília com uma irmã, onde logo começou a trabalhar. Conheceu seu primeiro companheiro, que bebia muito, a relação foi difícil terminando em separação, logo depois ele faleceu em decorrência da bebida. Em seguida, veio o segundo relacionamento, que não foi diferente, pois seu companheiro também bebia e mais uma vez separou-se. Atualmente, está sofrendo muito com o atual relacionamento, além de estar doente com fibromialgia e depressão.

Queixa que as brigas são constantes por causa da bebida. Seu companheiro tem alterações de comportamento quando está sob o efeito da bebida, lhe agride verbalmente e bate nos meninos. Outra questão que também a incomoda bastante é a auto-agressão como: apagar cigarros no próprio corpo, esquentar objetos e marcar o corpo, bater seu próprio corpo em paredes. Queixa-se, ainda, das dívidas contraídas pelo companheiro, pois não sabe para onde vai o dinheiro, e também da infidelidade.

Relata que é bom que ele fique internado, pois assim tem um pouco de sossego, pois quando sai da internação e volta a trabalhar a recaída é certa, uma vez que a empresa em que trabalha tem muita gente que bebe. Às vezes acha que é melhor ele aposentar, mesmo ganhando menos, talvez viveria melhor.

\subsubsection{Entrevista comgestor}

Entrevista realizada com o senhor W.A.B, chefe da seção onde trabalha o senhor C.A.M. Entraram na empresa juntos, no ano de 1981, relata que durante os anos iniciais o senhor C.A.M teve um bom desempenho, mas com o passar dos anos o hábito de beber foi se intensificando e com isto a produtividade foi diminuindo. A bebida atrapalhou o desempenho 
profissional, pois a tecnologia avançou na área de topografia e outras pessoas da equipe se reciclaram, mas o senhor C.A.M ficou arcaico, pois não mostrava interesse em se aperfeiçoar e a bebida sempre o atrapalhava.

C.A.M já chega ao trabalho embriagado, pois começa a beber muito cedo, mesmo assim ele não é impedido de ir para o trecho. No trabalho em campo, sempre ficam dois trabalhadores por conta do GPS (aparelho usado para medir distância), no caso do senhor C.A.M, sempre o companheiro fica e ele sai para beber. Entretanto acredita que o senhor C.A.M, pode melhorar e voltar a desempenhar suas funções satisfatoriamente, pois é um homem que tem facilidade para aprender bem, assim como para lidar com o serviço.

\subsection{A nálise Funcional}

São apresentadas, a seguir, as principais informações obtidas nas sessões de avaliação, com alguns comentários sobre o comportamento do paciente.

a) As queixas apresentadas foram: a falta de controle com relação ao hábito de beber, a depressão e as constantes brigas no ambiente familiar, piorando a saúde de sua companheira que sofre de depressão e fibromialgia e pondo em risco a segurança das crianças, já que tem alterações de comportamento quando está sobre efeito da bebida. Relatou desejo de mudar a forma como vem conduzindo sua vida, pois apesar de gostar de beber reconhece que o álcool já causou muitos prejuízos.

b) O paciente relatou que sua vida sempre foi difícil e que ficou pior quando aos 13 anos teve que deixar a escola para trabalhar por exigência dos pais. Outra dificuldade relatada é sobre o comportamento violento do pai. Ainda relata sobre a morte de sua primeira esposa prematuramente (aneurisma cerebral), como um evento que marcou sua vida, outro episódio que o paciente relata com pesar foi quando foi detido pela polícia acusado pela filha por agressão.

c) $\mathrm{O}$ paciente relatou que seus irmãos the exploram financeiramente, que só aparecem quando precisam de alguma coisa relacionada a dinheiro. Portanto, considera como sendo sua família apenas a companheira e os filhos e se preocupa com estes. Atualmente vive um conflito, afastado do trabalho, pensa em pedir a 
aposentadoria, porém seu salário sofrerá um grande rebaixamento, por outro lado voltar a trabalhar no mesmo local é quase certeza de voltar a beber.

Eu penso: o que devo fazer? Se eu voltar para o trabalho com certeza vou recair, pois apesar de gostar de beber sozinho, os meus companheiros muitos bebeme estar naquele trabal ho me lembra beber. Eu deixo a maquina trabal hando e vou beber, fumo mais de um maço de cigarros, quando encerra o expediente bebo mais e vou para o carteado. Ai penso em me aposentar mais o salário fica muito pouco, como fica minha família?.

d) Observou-se que o paciente reconhece seu problema e sua fragilidade perante o mesmo. Sua dificuldade em lidar com frustrações o remete a busca pelo álcool, como por exemplo, relata:

[...] já recaiu porque sua filha queria uma agenda cara ele não conseguiu dizer não, comprou a agenda e logo em seguida foi beber, na época estava a quase dois anos em abstinência, também as discussões de rotina com sua companheira, o levam a buscar solução na bebida.

Da mesma maneira, reconhece que a empresa na qual trabalha tem uma cultura que precipita o uso de álcool, pois, apesar de beber desde uma idade precoce (oito anos de idade), assiste ao que acontece aos seus companheiros

[...] muitos desenvolveramo hábito de beber ou pioraram depois que entraram lá, nas festas comemorativas tem muita bebida, antigamente o chefe de equi pe levava a bebida, para ser usada antes de começar o trabalho, principalmente se fosse umdia difícil.

A partir da análise funcional, observam-se comportamentos relevantes para a compreensão da situação vivenciada pelo paciente, assim como para o entendimento dos comportamentos atuais (Figura 2).

Figura 2 - Análise F uncional da Compreensão do Comportamento A tual do Paciente

\begin{tabular}{|c|c|c|}
\hline ANTECEDENTES & & \\
\hline $\begin{array}{l}\text { - História de vida } \\
\text { apresenta dificuldades }\end{array}$ & & $\begin{array}{l}\text { CONSEQUVENCIA } \\
\text { (reforço positivo) }\end{array}$ \\
\hline $\begin{array}{l}\text { privaçẫo das } \\
\text { necessidades básicas: }\end{array}$ & COMPORTAMENTO & $\begin{array}{l}\text { - O uso do álcool como } \\
\text { alivio dos sintomas }\end{array}$ \\
\hline $\begin{array}{l}\text { educaçẫo; } \\
\text { - Alcoolismo do pai; }\end{array}$ & $\begin{array}{l}\text { Iniciar aos } 8 \text { anos o hábito } \\
\text { de beber e fumar. }\end{array}$ & $\begin{array}{l}\text { CONSEQŪÊNCIA } \\
\text { (reforço negativo) }\end{array}$ \\
\hline $\begin{array}{l}\text { - Puniçã̃o severa do pai; } \\
\text { - Trabalho infanto/juvenil. }\end{array}$ & & $\begin{array}{l}\text { - Isolamento social, } \\
\text { desenvolvimento do uso } \\
\text { de álcool, raiva e } \\
\text { sentimento de culpa. }\end{array}$ \\
\hline
\end{tabular}

Fonte: Adaptação do modelo de COSTA e MARINHO, 2002 


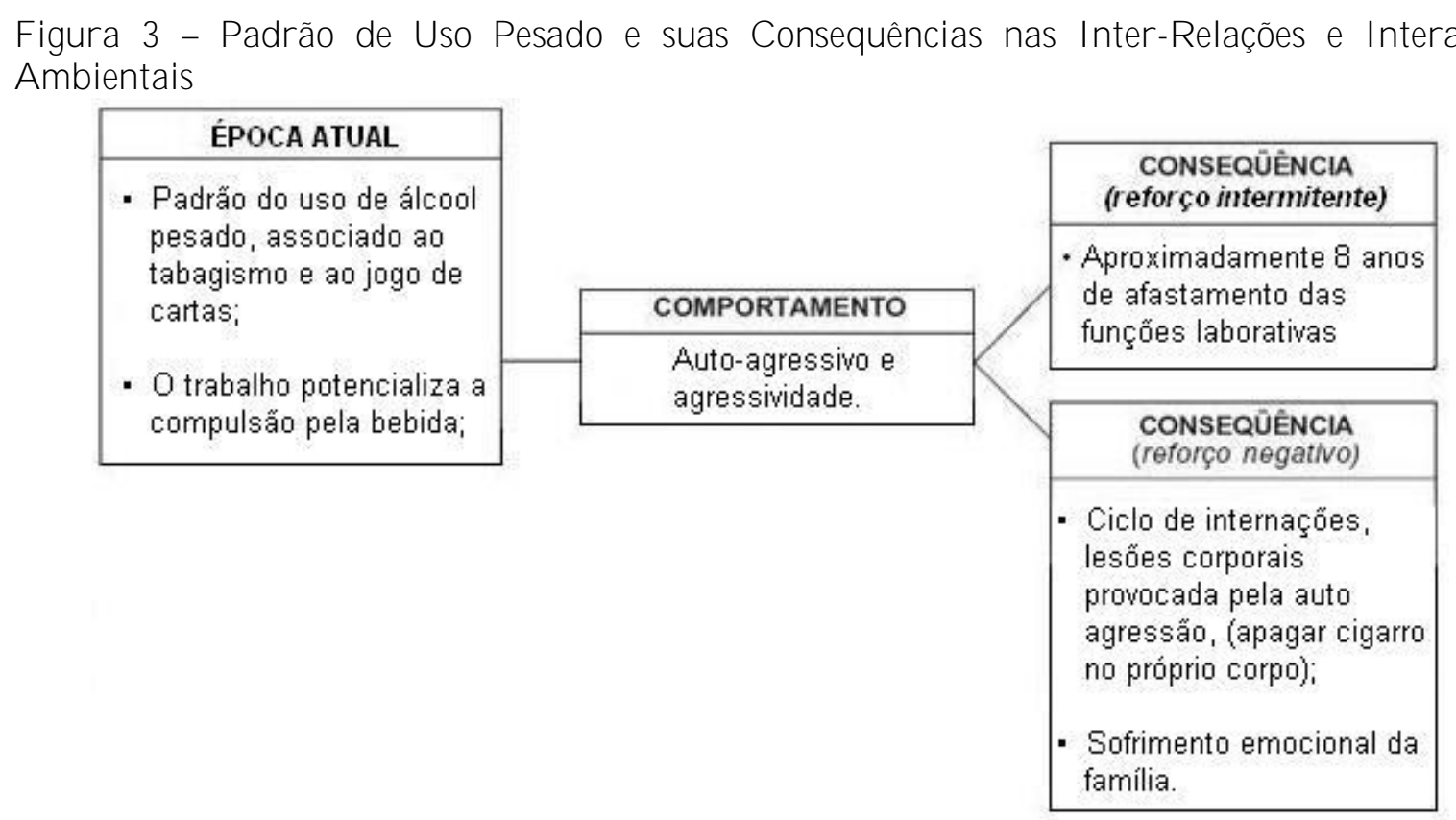

Fonte: Adaptação do modelo de COSTA e MARINHO, 2002

Neste trabalho, observa-se a construção do comportamento do hábito de beber, iniciado ainda na infância e adolescência, adentrando na idade adulta e chegando a um padrão de uso pesado e continum que preenche os critérios para o diagnóstico da Síndrome de Dependência Alcoólica - SDA, adotados por Edwar e Gross (apud FIGLIE, BORDIN, LARANJEIRA, 2004).

ß Estreitamento do repertório: conforme a dependência avança, os estímulos relacionam-se crescentemente com o alívio ou evitação da abstinência;

ß Saliência do uso: com o avanço da dependência, o indivíduo passa a priorizar a manutenção da ingestão do álcool;

ß Aumento da tolerância: o sistema nervoso central é capaz de desenvolver tolerância ao álcool e às drogas. Tolerância é definida como a diminuição da sensibilidade aos efeitos da droga, que ocorre como resultado da prévia exposição a ela;

ß Sintomas de abstinência: os sintomas de abstinência resultam de adaptações feitas pelo cérebro à interrupção ou redução do uso das substâncias; 


\section{ß Alívio ou evitação dos sintomas de abstinência pelo aumento do consumo:} constitui o mecanismo adaptativo do individuo ao aparecimento da síndrome de abstinência, envolvendo comportamentos que a evitem;

ß Percepção subjetiva da compulsão para o uso: é a percepção que o indivíduo tem de sua falta de controle;

ß R einstalação após a abstinência: é o processo por meio do qual uma síndrome que levou anos para se desenvolver pode se reinstalar dentro de 72 horas de ingestão.

\subsection{Intervenção}

O paciente foi encaminhado para internação devido o consumo excessivo de álcool e não está respondendo a intervenção ambulatorial. Entretanto, entende-se que a internação neste caso funciona como uma medida paliativa, porém necessária, mas no que tange a prevenção da recaída o paciente não é assistido, portanto é importante contar com outras opções, dentre as quais, pode-se citar as seguintes modalidades: ambulatorial, internação domiciliar, hospital-dia (DIEHL, CORDEIRO e LARANJEIRA, 2010).

No tratamento de alcoolistas, a combinação das abordagens farmacológicas e psicoterápicas facilitam a adesão do paciente ao programa de tratamento e aumenta a chance de manutenção da condição de abstinência. Sabe-se que um tratamento deve atender às necessidades particulares de cada individuo, desprezando um modelo de "tamanho único", no entanto, estudos recentes ressaltam a importância de aliar terapia conjugal, sessões informativas a respeito dos efeitos da substância utilizada, bem como dos efeitos da medicação prescritas e as possíveis ocorrências durante o tratamento (DIEHl, CORDEIRO e LARANJEIRA, 2010).

Em relação ao tratamento farmacológico, nos últimos 10 anos, tem sido observado um significativo aumento no uso de intervenções terapêuticas farmacológicas para o tratamento do alcoolismo devido aos avanços nos conhecimentos da neurociência, englobando os sistemas de neurotransmissores envolvidos com estruturas mesocorticolímbicas e suas fisiopatologias. Nesse contexto, tem crescido a importância das monoaminas, em especial a dopamina, firmando-se entre os estudiosos como uma via final comum que leva ao comportamento de busca pela droga e fissura. 
Tem-se observado um interesse crescente pelo desenvolvimento de fármacos que possam auxiliar na prevenção das recaídas e no manejo da fissura (craving) pelo álcool. O conceito de craving pelo álcool, no entanto, não está completamente definido, uma vez que diversos estudos o descrevem e definem de formas diferentes, mas se acredita em sua existência e em sua íntima relação com as recaídas (DIEHL, CORDEIRO e LARANJEIRA, 2010).

Embora estudos mostrem a importância do tratamento farmacológico na Síndrome da Abstinência do Álcool, em se tratando dos antietanol raramente são prescritos nas unidades de internações e ambulatoriais, o tratamento farmacológico é direcionado as comorbidade, é comum o uso de antidepressivos, ansiolíticos, antipsicóticos e anticonvulsivantes.

Quanto à farmacologia aplicada ao tratamento do alcoolismo, à medida que aumentam as evidências cientificas do uso de uma combinação medicamentosa junto com uma intervenção psicológica breve no tratamento do alcoolismo, aumentam também as possibilidades de adequação do tratamento dessa patologia em ambientes de atenção primária.

Entre as medicações já existentes para tratamento do alcoolismo cita-se: Dissulfiram, utilizado desde 195, nos Estados Unidos, foi o primeiro medicamento aprovado pela Food and Drug Administration - FDA para o tratamento da Síndrome da Dependência Alcoólica SDA. No Brasil, é o único sensibilizante ao álcool atualmente disponível. É comercializado com o nome de Antietanol.

Naltrexona é um antagonista opioide, utilizado como coadjuvante das intervenções psicossociais no tratamento ambulatorial da SDA. Autorizado pela FDA em 1995, é comercializado no Brasil com o nome de REVIA. O Acamprosato vem sendo utilizado em paízes europeus, desde 1996, aprovado pela FDA para tratamento do alcoolismo (DIEHL, CORDEIRO e LARANJEIRA, 2010).

O paciente em discussão encontra-se em uso de antedeprssivo citalopram de 20mg, hipnótico flurazepam de 30mg, e antieplético lamitor de 100mg. No momento o paciente encontra-se egresso de uma internação de sessenta e dois dias, durante a qual foi submetido a exames clínicos e de neuroimagem, quanto aos exames laboratoriais o paciente apresenta resultados considerados dentro dos padrões normais, quanto ao de neuroimagem a Tomografia Computadorizada (Tc $30 \mathrm{mCi}$ - 1.110MBq) encontrou: múltiplos déficits perfusionais cerebrais difusos, do hemisfério cerebelar, tálamo e gânglios da base direitos 
com aspectos de microinjúrias vasculares. Tais achados podem ser atribuídos a intoxicação exógena e associação com eventos isquêmicos não pode ser afastada. Há sinais indiretos de atrofia cerebelar.

Diante do quadro, o plano de tratamento deve considerar desde a história clínica, aos achados neurológicos e aspectos psicossociais, para que a escolha de estratégias adotadas envolva uma abordagem interdisciplinar que deva prever técnicas de reabilitação cognitiva para remediar alterações encontradas, pois dependentes de álcool que se mantém em abstinência tendem a demonstrar recuperação em determinadas área do cérebro (CUNHA, NOVAES, 2004).

Tratamento farmacológico adequado é de relevante importância, bem como a psicoterapia focada no modelo cognitivo de Beck (1996), envolvendo segundo Brewin (1989 apud FIGLIE, 1999) o terceiro tipo de mudança cognitiva que envolve avaliar conscientemente as opções e encorajar a persistência no seu uso. Este é o último grupo de abordagens cognitivas à tenacidade e mudança comportamental que tem dominado a literatura sobre o tratamento da dependência química. 


\section{RESULTADOSE DISCUSSÃO}

Este trabalho apresenta como aspecto importante as consequências do uso nocivo de álcool para a vida humana e, principalmente, o impacto deste no âmbito do trabalho, que vai desde as dificuldades nas interrelações aos prejuízos na produtividade, o consumo de álcool ao longo dos anos acarreta danos físicos, morais e sociais.

Quanto à qualidade de vida, avaliada pelo SF12, evidencia prejuízo nos seguintes domínios: capacidade funcional, aspectos físicos, aspectos emocionais, estado geral de saúde, aspectos sociais, dor e saúde mental, com prevalência na capacidade funcional. A qualidade de vida relaciona-se mais com a forma de uso (dependência, abuso) do que com o padrão de consumo (frequência, quantidade ou tipo) (PATIENCE etal, apud FLECK, 2008).

O padrão de dependência de nicotina foi avaliado pelo Fagerstrom teste, para o qual o paciente indicou o consumo de 10 cigarros ao dia, o referido teste considera para o consumo de 10 cigarros por dia ou menos, uma pontuação ( 5 pontos) que corresponde um grau de dependência médio. Estudos mostram que o hábito de beber intensifica o fumar (ROSENGREN et al, apud FIGLIE, 2004).

Quanto à severidade da dependência alcoólica avaliada no SADD, o paciente obteve um escore total de 32 pontos, que corresponde na escala de avaliação a alternativa 03 , que se refere ao grau de dependência como uma dependência grave.

Quanto às conseqüências do hábito de beber avaliadas no DRINC, apresenta prejuízos nas áreas: físico, interpessoal, intrapessoal, controle do impulso responsabilidade social, com prevalência na área controle dos impulsos. Perfazendo um escore total de 41 pontos que corresponde à classificação 09 , sendo considerado pelo inventário muito alto.

Quanto à motivação, o instrumento URICA norteou o processo de avaliação da motivação baseado no modelo de Prochaska e Diclemente (1986), primeiramente descritos como uma porta giratória. Recentemente, Prochaska et. al. (1992) apresentaram um modelo em espiral que descreve os estágios de mudança: pré-contemplação, contemplação, preparação, ação e manutenção ilustradas por um espiral.

De acordo com o instrumento utilizado, o paciente encontra-se no estágio de contemplação, onde, simultaneamente ou em alternações rápidas, experimenta razões para a preocupação e para a despreocupação, motivação para a mudança e para continuar inalterado. 


\section{Figura 4 - M odelo em espiral dos estágios de mudança de Prochaska e cols (1992)}

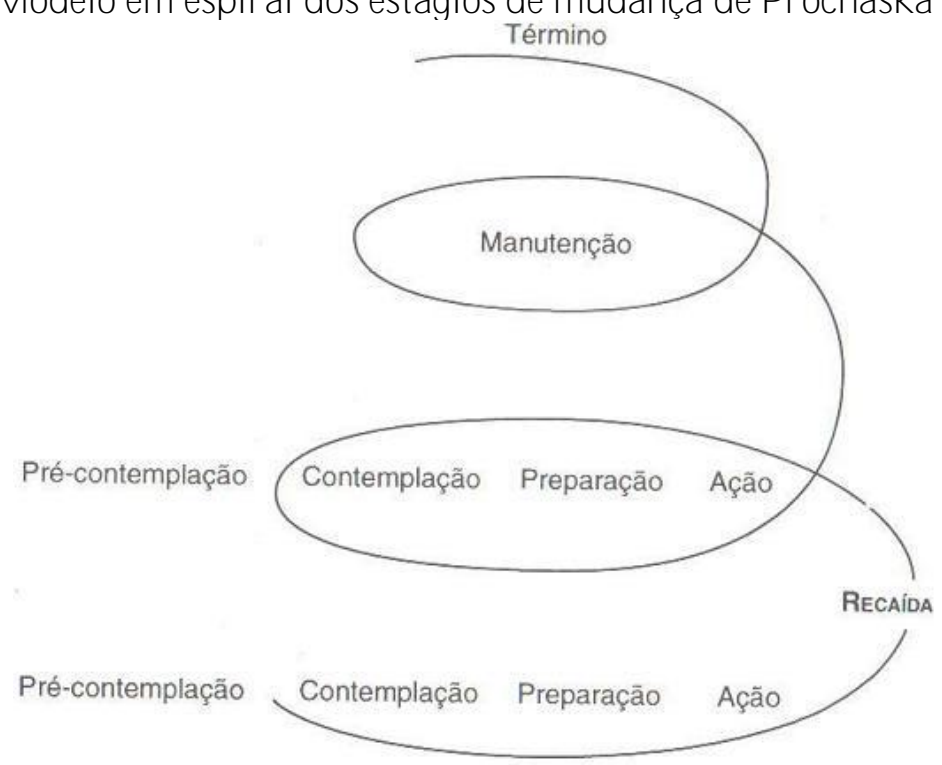

Quanto ao impacto do uso nocivo de álcool para a vida laboral do paciente, aplicouse o componente do indicador DALY (YLD) que corresponde aos anos de vida perdidos devidos a incapacidade, os achados corresponde à seguinte descrição:

B $\mathbf{r}$ é a taxa de desconto aplicada em relação aos anos de vida perdidos no futuro, com o objetivo de estimar os anos de vida perdido no presente. Para estudos da Carga Global da Doença recomenda-se a taxa de 3\% em analise de custoefetividade na saúde Gold et al (apud FIOCRUZ, 2000). Portanto neste caso $\mathbf{r}$ representa $3 \%$

ß â é o parâmetro para função de ponderação da idade, onde â $=0,04$;

ß C é a constante 0,1658 ;

ß $\mathbf{a}$ é a idade do surgimento da doença, onde $\mathbf{a}=35$;

ß $\mathbf{L}$ é a duração da incapacidade, onde $\mathbf{L}=8$;

B D é o peso da incapacidade, onde $\mathbf{D}=0,6$ (valor recomendado por Murray, 1996).

ß E é constante de Euler 2,718.

ß YLD $=5,74$ 
$\mathrm{O}$ peso da incapacidade neste estudo corresponde a 5,74 valores mais alto que o estimado nos estudos populacionais, onde os anos vividos com incapacidade corresponde a $2,5 \%$.

Considera-se que o percentual encontrado representa um prejuízo significativo na capacidade laborativa do paciente e, consequentemente, na economia da empresa. Este impacto relaciona os custos diretos representados pelos recursos consumidos devido à intervenção e custos indiretos representados pelas perdas na produtividade por causa da doença ou morte (FRIEDLAND, et.al. 2001).

Os custos intangíveis apresentam-se na perda da qualidade de vida, no aspecto social e moral que afeta a dinâmica familiar provocando danos, tais como: baixa no rendimento escolar das crianças. adoecimento da companheira, que por sua vez resiste em realizar um tratamento focado na co-dependência, o que evidencia uma grande dificuldade de romper com crenças centrais, que contribuem para a repetição de padrões em sua vida, sendo que, assim mesmo, as tentativas de ajudar o companheiro às vezes contribuem para a manutenção do quadro. 


\section{CONCLUSÃO}

A síndrome de dependência do álcool é um problema de saúde pública de primeira magnitude, sendo um dos transtornos mentais mais prevalentes na comunidade. Trata-se de uma patologia crônica, com muitas recidivas, inúmeros prejuízos clínicos, sociais, laborais, familiares e econômicos e, frequentemente, está associada a acidentes e situações de violência em muitos países (DIEHL, CORDEIRO e LARANJEIRA, 2010).

A região das Américas é a zona do mundo em que o consumo de álcool contribui com maior proporção relativa de mortalidade e anos de vida perdidos por morte prematura e incapacidade. O álcool é o primeiro fator de risco para doenças e morte prematura, sendo mais importante ainda que outros fatores como o tabagismo, a hipercolesterolemia, o sobrepeso, a desnutrição e os problemas de saneamento.

É uma droga que provoca dependência e a origem de mais de 60 tipos de doenças e lesões. O álcool é responsável por causar sérios problemas, danos sociais, mentais, e emocionais, como criminalidade, violência familiar com elevados custos para a sociedade.

O padrão de consumo de risco para a saúde exata é definido pela OMS como consumo regular de 20 a 40g diárias para mulheres e 40 a $60 \mathrm{G}$ para homens. Prejudicial mais de $40 \mathrm{~g}$ dia em mulheres e mais de 60 em homens. Excessivo episódio circunstancial, também chamado beber em bingue drinking, implica no consumo por parte do adulto, de $60 \mathrm{~g}$ de uma só ocasião.

A dependência é um conjunto de fenômenos condutores, cognitivos e fisiológicos, no qual o uso de álcool se transforma em prioritário para o indivíduo, em contraposição com outras atividades e obrigações que em algum momento tiveram maior valor para ele (OPAS, 2008).

O mesmo trabalho realizado pela Organização Panamericana de Saúde - OPAS, em 2008, intitulado Alcohol y Atención primaria de la Salud, sugere a implantação de intervenções breves em centros de atenção primária a saúde para reduzir os problemas de consumo de álcool entre bebedores de risco, onde 1 em cada 8 pacientes de beneficiariam.

O custo efetividade dos programas de intervenção breve deveria ser financiado por provedores de fundos dos serviços de saúde com objetivo de reduzir o consumo e os riscos. A 
implantação de tais programas em grande escala, reduziriam em uma margem significativa as mortes e incapacidade devido ao uso de álcool.

Os dependentes devem receber tratamento especializado quando se tratarem de indivíduos que fracassaram em intenções prévias de tratamento e apresentaram complicações severas, quando haja evidências de comorbidades médicas e psiquiátricas graves e quando o tratamento não pode ser manejado por equipe de atenção primária.

O tratamento especializado inclui abordagens condutoras e farmacoterapia, o treinamento de habilidades sociais, modelo de reforço na comunidade, terapia de conduta dos pares, as quais estão entre as abordagens mais efetivas, pois ressaltam as habilidades da pessoa para suspender ou reduzir o consumo por meio da aprendizagem de técnicas de autocontrole, do incremento da motivação e do reforço aos sistemas de suporte social. 


\section{REFERÊNCIAS}

AGÊNCIA NACIONAL DE SAÚDE SUPLEMENTAR. Diretrizes assistenciais para a saúde suplementar. Rio de Janeiro, 2008. Disponível em: $<\mathrm{http}: / / \mathrm{www}$. google.com.br/\#hl=ptBRBR\&q=diretrizes+assistenciais+para+sa\%C3\%Bde+su plementar\&meta $=\& a q=f \& o q=$ diretrizes + assistenciais + para + sa $\% \mathrm{C} 3 \%$ BAde+suplementar\&fp $=100 \mathrm{a} 0 \mathrm{~d} 77 \mathrm{~b} 1901992>$. Acesso em: 04 nov. 2009.

ANDERSON P; GUAL A; COLON J. Alcohol y atención primaria de la salud: informaciones clínicas básicas para identificación y el manejo de riesgos y problemas. Washington: Organização Panamericana de Saúde, OPS, 2008. Disponível em: <http://www.paho.org/Spanish/DD/PUB/Alcohol_Aten_prim_web.pdf> Acesso em: 20 out. 2009.

BRASIL. Secretaria Nacional Antidrogas. Prevenção ao uso de álcool e outras drogas no ambiente de trabalho: conhecer para ajudar. Brasília: Disponível em: <www.senad.gov.br> Acesso em: 10 out. 2009.

CAMELIER, Aquiles Assunção. Avaliação da Qualidade de Vida relacionada à saúde em pacientes com DPOC: estudo de base populacional com o SF-12 na cidade de São Paulo-SP. São Paulo, 2005. Tese (Doutorado) Universidade São paulo. Escola Paulista de Medicina. Programa de Pós-graduação em Pneumologia. Disponível em: <http://www.platinoalat.org/docs/thesis_a_camelier_2004.pdf> Acesso em: 6 jul. 2009.

CAMPOS, Silvana Elisa G; MARINHO Maria Luiza. Um modelo de apresentação de análise funcionais do comportamento. Estud. Psicol; Campinas, Vol. 19. n. 3. Set. Dez.2002. Disponível em: <http://www.scielo.br/scielo.php?pid=S0103166X2002000300005\&script=sci_arttext\&tlng=pt> Acesso em: 20 set. 2009.

CARLAT, Daniel J. trad. CALEFFI, Andréa; DORNELlES, Cláudia. Entrevista psiquiátrica. Porto Alegre: Artmed, 2007, 312 p.

CUNHA Paulo; NOVAES Maria Alice. Avaliação neurocognitiva no abuso e dependência do álcool: implicações para o tratamento. Rev. Bras. Psiquiatr, São Paulo, vol. 28, n. 4, dez. 2006. Disponível em: <http://www.scielo.br/scielo.php?script=sci_arttex\&pid=S1516444462006000400014 \&lng=e>. Acesso em: 4 ago. 2009.

DIEHL, Alessandra. Et al. Tratamento farmacológico para dependência química: da evidência científica à prática clínica. Porto Alegre: Artmed, 2010.

FIGLIE, Neliana Buzi. Motivação em alcoolistas tratados em Ambulatório Específico para Alcoolismo e em Ambulatório de Gastroenterologia. [Mestrado]. São Paulo: Universidade Federal de São Paulo, 1999. Disponível em: 〈www.nelianafiglie.com.br〉. Acesso em: 10 jul. 2009.

FIGLIE, Neliana Buzi; BORDIN Selma; LARANJEIRA Ronaldo. Aconselhamento em dependência química. São Paulo: Roca, 2004, 540 p. 
FIO-CRUZ. Fundação Oswaldo Cruz. Projeto carga da doença no Brasil. Escola Nacional de Saúde Pública, Rio de Janeiro. 2002. Disponível em: <http://www4.ensp.fiocruz.br/projetos/carga/apresentacao.htm> Acesso em: 13 ago. 2009.

FLECK, Marcelo Pio A. et al. A avaliação de qualidade de vida: guia para profissionais da saúde. Porto Alegre: Artmed, 2008, 228 p.

FOCCHI, Guilherme Rubino de A. et al. Dependência química: novos modelos de tratamento. São Paulo: Roca, 2001, 165 p.

FRIEDLAND, Daniel J. et al. Medicina baseada em evidências: uma estrutura para a prática clínica. Rio de Janeiro: Guanabara, Copyright, 2001, 231 p.

GALLASI, Andréa Donati; et. Al. Custos dos problemas causados pelo abuso do álcool. Rev Brasileira Psiquiatria, São Paulo, supl 1, fev. 2008. Disponível em: <http://.hcnet.usp.br/ipq/revista/vol35/s1/25.htm> Acesso em: 30 de set. 2008.

GORENSTEIN, Clarice; ANDRADE, Laura H; WALDO, Antonio. E scalas de avaliação clínica em psiquiatria e psicofarmacologia. São Paulo: Lemos, 2000, 438 p.

HANSON; RUSHBY FOX JÁ. Calcularing and presenting disability adjusted life years (Dalys) in cost-effectiveness analysis. Health Policy and Planing, Oxford journals. London, vol.16, n.3, p. 326-331, mar. 2001. Disponível em: <http://heapol.oxfordjournals.org/cgi/content/abstract/16/3/326>. Acesso em: 11 nov. 2009.

ISKAND, Jamil Ibrahim. Normas da A BNT : comentadas para trabalhos científicos. 4. ed. Curitiba: Juruá, 2009.

LARANJEIRA, Ronaldo. et al. Revisão técnica cientifica. In: DUARTE, Paulina do Carmo VI Levantamento Nacional sobre os padrões de consumo de álcool na população brasileira. Brasília: Secretaria Nacional Antidrogas, 2007, 76 p. Disponível em: <www.uniad.org.br>. Acesso em: 5 set. 2009.

MCCONNAUGHY; PROCHASKA; VELICER. University of rhode island change assessment scale URICA. 1983, validada por Figlie 1999. Disponível em: <www.nelianafiglie.com.br>. Acesso em: 5 set. 2009.

MCHORNEY, CA; WARE, JE; RACZEK, AE. The MOS 36-Item Short-Form Health Survey (SF-36):II. Psychometric and clinical tests of validity in measuring physical and mental health constructs. M ed C are. 1993;31(3):247-63.

MILLER, William R; ROLLNICK Stephen. trad. CALEFFI, Andrea; DORNELLES, Cláudia. Entrevista motivacional: preparando as pessoas para a mudança de comportamentos adictivos. Porto Alegre: Artmed, 2001, 287 p.

MORAES Edilaine; et al. Conceitos introdutórios de economia da saúde e o impacto social do abuso de álcool. Rev. brasileira Psiquiatria. São Paulo, vol. 28, n. 4, dez. 2006. Disponível em: $\langle$ http://www.scielo.br/scielo.php?script=sci_arttex\&pid=S151644462006000400014\&l $>$. Acesso em: 04 agost. 2009. 
MURRAY,C.J.L. Quantifying the burden of disease: the technical basis for disabilityajusted life yars. Word Heaalth Organization, Bulletin 72, (3)427-445, 1994. Disponível em: <http://www.who.int/publications/en/>. Acesso em: 11 nov. 2009

NEVES, Delma Pessanha. Alcoolismo acusação ou diagnóstico?. Cad de Saúde Pública; Rio de Janeiro, Vol. 20. Fev. 2004. Disponível em: <http://www.scielo.br/scielo.php?script=sci_arttext\&pid=S0102311X200400010000〉. Acesso em: 12 de agost. 2009.

NÚCLEOS, Centro de Medicina Nuclear. E C D -Tc (30mC i- 1.110M Bq). Reg. 64912.

PICCOLOTO, Luciane Benvegnu; et.al. Os estágios motivacionais de alcoolistas internados devido a doenças clínicas em hospitais gerais. Rev. psiq. clínica, São Paulo, vol. 33, n.4, fev. 2006. Disponível em: <http://www.scielo.br/scielo.php?pid=S0101$60832006000400005 \&$ script=sci_abstract\&tlng=pt $>$. Acesso em: 28 jan. 2010.

PORTILHO Conceição. E statística aplicada à saúde. Aula ministrada na Unimed Centro Oeste e Tocantins, out/nov. 2009.

RAISTRICK. Short-Form Alcohol Dependence Data SADD. 1983 Padronizado por Jorge e Masur 1986. Disponível em: <www.nelianafiglie.com.br>. Acesso em: 28 jan. 2010.

RAMOS, Sergio de P; BERTOLOTE, Manuel J. et al. Alcoolismo hoje. Porto Alegre: Artes Médicas, 1997, 240p.

SÁ Edvaldo B. E conomia da saúde: indicador DALY. Aula ministrada na coordenação de saúde, Instituto de Pesquisa Econômica Aplicada IPEA, out/nov. 2009.

SASSI, Franco. C alculating Q alys, comparing Q aly and Daly calculations. Health Policy and Planing, Oxford journals. London, vol. 21, n. 5, p. 402-468, july. 2006. Disponível em: <http://heapol.oxfordjournals.org/cgi/content/abstract/21/5/402>. Acesso em: 11 nov. 2009

TONIGAN; MILLER. The Drinker Inventory of Consequences DrInc. 1995. Disponível em: <www.nelianafiglie.com.br>. Acesso em: 11 nov. 2009

VASSMAN, Magda. Alcoolismo no trabalho. Rio de Janeiro: Garamond, 2004, 219 p. 